\title{
IAMJ
}

INTERNATIONAL

AYURVEDIC

MEDICAL JOURNAL

Review Article

ISSN: 2320-5091

Impact Factor: 6.719

\section{CHANGING FOOD HABIT - A RE-EVALUATION}

\author{
Niranjana Gopal $K^{1}$, Athri S.S ${ }^{2}$, Jishnu $\mathbf{R}^{3}$ \\ ${ }^{1}$ PG Scholar, ${ }^{2,3}$ Associate Professor \\ Dept. Samhitha \& Siddantha \\ Pankajakasthuri Ayurvedha Medical College \& Post Graduate Centre \\ Kattakada, Thiruvananthapuram
}

Corresponding Author: niranjanagopalk@gmail.com

\section{https://doi.org/10.46607/iamj1109052021}

(Published Online: May 2021)

Open Access

(C) International Ayurvedic Medical Journal, India 2021

Article Received: 14/04/2021 - Peer Reviewed: 04/05/2021 - Accepted for Publication: 05/05/2021

Check for updates

\section{ABSTRACT}

The supporting pillar of our body includes food, sleep \& Bramacharya (Stay in conduct). A proper, optimum and skilful use of these triad maintains the integrity, physical, immunological strength, complexion, growth, nourishment, till full length of life. Among them food acts as the foundation or rather energy provider for the other two components. Most health problems develop due to the wrong eating habits and cooking methods.

When we look back, to 1970's Kerala state had already achieved the criteria similar to the health status which was to be achieved in 2000 as per the WHO criteria. But unfortunately, the condition got altered and the state got into the list of top ten among the lifestyle disorders.

Foods are altered, treated, processed, coloured, sulphurated, embalmed, adulterated, preserved, pickled, cooked sterilised and pasteurized leading to deprivation of nutritional values, which is the curse of this age. The modern society got merged into the regimens of tea, coffee, cold- drinks, instant food, bottled and canned foods, alcohol consumption, smoking, drug addiction and so on. The commercial advertisement seems to bind a ready sale to the credulous miss informed public about the nutrition supplements. There is a high demand among the public for imported vegetables, fruits etc which actually do not suit the climate of India.

This article will throw the light in the necessity of rethinking the suitability according to seasons, places, climates, occupation, way of life etc, which is the matter of the hour. This in turn will ponder over the problem in a very 
critical manner and analyse various merits and demerits to rearrange them for the upliftment of good health and living.

Keywords: food, Nidra (Sleep)

\section{INTRODUCTION}

Ayurveda, a traditional system of medicine that originated over three millennia ago in the South Asian region, offers extensive insights about food and health based on certain unique conceptual as well as theoretical positions. There has been an increased global interest in traditional medicine. Efforts to monitor and regulate traditional herbal medicine are underway. Food is an essential requirement in life and one can attain good health by following a proper, natural diet. ${ }^{1}$

Out of the three Upasthambhas (supports of life), i.e. Ahara (diet), Nidra (sleep) and Brahmacharya ${ }^{2}$ (Stay in conduct)., the first one has been given more importance and considered to be the best in Ayurveda. A proper, optimum and skilful use of these triads, human body to maintain its integrity, being enriched with Bala (physical and immunological strength), Varna (complexion) and Upachaya (growth of nourishment), till full length of life. Most health problems develop due to the wrong eating habits and cooking methods ${ }^{3}$. The food is said to be cause of stability for all living beings. There is nothing else except diet for sustaining the life of living beings.

When we look back, in 1970's itself our state Kerala has achieve the criteria for health status of 2000, a dramatic change in condition of health after post-independence.

But unfortunately coming to present scenario the condition gets revised because now state is in the list top ten among the lifestyle disorders.

So, it's the apt time to think why, what, happen and how we can repair.

\section{Materials and method}

Our ancient Ayurvedic classics gives clear hints about the suitable and unsuitable food stuffs in health and disease through each and every treatment chapters and the chapters of Krithannavarga (prepared food item). But the preparation methods are described only for some of them. I think it happened like this because at the time there existed some well - established pakasasthra textbooks for giving guidelines to the common people through the authority (kingdom).

One among them was the pakasastra text of nala and another one is kshemakuthukala. 'Kshemakutuhalam' was a curious $17^{\text {th }}$ century work on Ayurveda dietetics written by Kshemasharma, an Ayurvedic physician. The book discussed about traditional Indian cuisine. The 15 types of appetizers or kshutbodhaka articles are the unique contribution of Kshemasharma.

Classics like Charaka Samhitha, Susrutha Samhitha, Ashtanga Sangraha, Bhavaprakasa etc, have detailed mention of food habits. But by comparing all the classics in a detailed manner it is found that Bhavaprakasha relatively included more about these.

\section{Result}

India might be a third world country based on socioeconomic development parameters, in terms of our lifestyle and health, we have the same morbidity profile of a first world nation. Lifestyle diseases like cardiovascular, diabetes, hypertension, asthma and respiratory as well as cancers are on the rise.

India has the highest number of diabetics at 50.8 million according to the World Health Organization, though only $11 \%$ of the population has health insurance. This figure is set to increase to 73.5 million by 2025. Twenty-five million suffer from cardiovascular diseases which amount to $60 \%$ of the global figure. ${ }^{4}$ Overcrowding and bad living conditions also increase stress leading to coronary heart diseases, asthma and cancers. Urbanization makes for a sedentary life leading to greater obesity.

When looking behind the reason for this, the change in the dietary pattern is the main culprit and also change in the economic status of people also play a role. Where, in past 10 year the economic status of people was poor and also intake of food was limited as well as the are hardworking, but now all are preferring white 
collar job and also most of them have enough money, which lead to increase in food quantity as well as improper diet. even the emergence of continental food, various restaurants such as chines, Italian etc attract people and lead to intake of food which not suite for our climate as well as out body constitution.

\section{Traditional food habit.}

Many of the things we do, including the food we eat, and activities are a result of tradition and habit. traditional Habitat and way of life show some relation and similarity to the practice as given by Ayurvedic.

Natural household seasoning material spices and condiments had been used as handy readymade remedies from long time back. Over a long period of time and countless personal experience, multifarious application of these kitchen stores has entered the domestic lore of mothers. They besides being valuable flavouring agent, serves as medicated material. whose significance is easily varied. The common notion that foods can be used as medicine is largely due to the medicated utility of this material. The food prepared by our ancestors furnish many details of its suitability in the different condition. If we go through the daily food items many examples are elicited in a very genuine way. The regular use of turmeric in curries nullify any toxic content present in food also helps to purify blood. Seasoning with mustard seeds and oil helps to alter the structure of fat molecule which in turn harmless to the body. Addition of curry leaves, ginger, spices, Chilli, tamarind etc. Increases the relish and accounts for proper digestion and assimilation. The use of flavouring agent by its exquisite taste, aroma texture and colour not only to boost desire towards food but also adds to conception of food and splitting of heavy food. Food and curries were prepared according to the availability and seasonal changes which proved beneficial to health. Some traditionally used combination with their suitability in healthy and disease conditions are enlisted in the follows

Several preparations as lemon rice and turmeric rice, curd rice is seen in specific regions and communities. In hard working people, there will be excess loss of energy and salt through excessive sweating. It was supplemented by taking cooked rice water with salt, buttermilk with more salt, gruel with salt etc. Moreover, porridge kept overnight was used which gives strength and coolness, along with this brined items and pickles were to use with tuber preparations as yam, Colocasia etc. Tapioca with fish curry, fish curry with Malabar tamarind, pickle of Mango, chutney with mango, tamarind etc have been used, which enhances the strength digestion and replenishment of the body. Chutneys made pounding fried coconut grating, chillies, turmeric and salt examples were considered as relishing appetizer present in almost all meal shelves. Milk and milk preparation are used in several families which nourish the body and decreases malaise. The habit of taking card, plantain fruit and sugar at the end it was practice will help the digestion and easy evacuation.

\section{Ahara and Roga (Food and Diseases)}

Table 1: Ayurveda has mentioned many food items as apathy for many roga(diseases). Here I'm enlisting some of them. ${ }^{5}$

\begin{tabular}{|l|l|l|}
\hline Sl.no & Food & Roga \\
\hline 1. & Fired and baked food, pickles, sour and oily food, curd, black gram horse gram etc.. & Amla pitta \\
\hline 2. & Pishtaanna, fried item, jaggery preparation & Arsas \\
\hline 3. & Pishtanna,payasa, anoopamamasa, milk, curd & Kushta \\
\hline 4. & New creals, pistanna, ice-cream, sweet item like jilebi, laddu, rasagula etc. curd, jaggery, jam, etc & Premeha \\
\hline 5. & Krisara, baked food, coco product, salted food, deep fried food & Shopa \\
\hline 6. & Peya, pishtanna, pungent food, abhishandhi ahara & Visarpa \\
\hline 7. & Payasa, oilcake, pistanna, pungent, hot food & Vrana \\
\hline
\end{tabular}


When an individual intake these food item in a daily basis lead to many problems.

Table 2: Food item and indication - Bhavaprakasa ${ }^{5}$

\begin{tabular}{|c|c|c|c|}
\hline Sl.no & Food item & Indication & Present corelation \\
\hline 1 & Mamsaringataka & $\begin{array}{l}\text { Causes dryness, increases Vata, give strength. } \\
\text { Best suited to those of strong digestive fire Be- } \\
\text { stows strength, is an aphrodisiac, helps taste, } \\
\text { mitigate Vata, }\end{array}$ & Samosa \\
\hline 2 & Kundalini & $\begin{array}{l}\text { Increases, Kapha bestows strength, easy for di- } \\
\text { gestion, mitigate Pitha and Vata. }\end{array}$ & Jilebi' \\
\hline 3 & $\begin{array}{l}\text { Bhaktha/Boiled } \\
\text { rice }\end{array}$ & $\begin{array}{l}\text { Tasty, easily digestible, increases digestive fire, } \\
\text { good for health, bestows contentment. }\end{array}$ & $\begin{array}{l}\text { Porridge prepared from un- } \\
\text { washed rice, water not } \\
\text { drained and consumed cold is } \\
\text { hard for digestion, causes loss } \\
\text { of taste and increases Kapha. }\end{array}$ \\
\hline 4 & $\begin{array}{l}\text { (Krisara) } \\
\text { Kichadi }\end{array}$ & $\begin{array}{l}\text { Increases semen and strength, hard for diges- } \\
\text { tion, increases Pitha and Kapha, causes flatu- } \\
\text { lence, help to eliminate faeces and urine. }\end{array}$ & $\begin{array}{l}\text { Generally, it is called as } \\
\text { Kichadi, it is very commonly } \\
\text { prescribed for intestinal com- } \\
\text { plaints }\end{array}$ \\
\hline 5 & $\begin{array}{l}\text { Angarakarkati/ } \\
\text { Fulka }\end{array}$ & $\begin{array}{l}\text { Stoutening, increases semen, light for } \\
\text { digestion, increases digestive fire and Kapha, } \\
\text { bestows strength, cures rhinitis, dyspnea and } \\
\text { cough }\end{array}$ & $\begin{array}{l}\text { It is prepared by wheat flour } \\
\text { without using any oil medium. } \\
\text { It is cooked directly on burn- } \\
\text { ing coal. So, it can be kept for } \\
\text { some time without spoilage. } \\
\text { Generally, it is used by the } \\
\text { North Indian and it may be } \\
\text { considered as the fulka }\end{array}$ \\
\hline 6 & $\begin{array}{l}\text { Harisa/Mixed } \\
\text { Biriyani }\end{array}$ & $\begin{array}{l}\text { Strengthening, mitigates Vata and Pitha, heavy, } \\
\text { increases semen, unctuous, laxative and helps } \\
\text { in fracture healing }\end{array}$ & Mixed biriyani \\
\hline 7 & Bedhamika & $\begin{array}{l}\text { Increases breastmilk, Pitha and Kapha, cures piles, } \\
\text { facial palasy, dyspnoea, pain of abdomen due to } \\
\text { digestive disorder }\end{array}$ & $\begin{array}{l}\text { (modaka prepared with wheat } \\
\text { black gram) }\end{array}$ \\
\hline 8 & Rotika & $\begin{array}{l}\text { Bestows strength, helps taste, stoutening, nourish- } \\
\text { ing, mitigates Vata, increases Kapha, good for } \\
\text { those who leave keen digestive fire }\end{array}$ & (pancake) \\
\hline 9 & Purika & $\begin{array}{l}\text { Helps taste, hard for digestion, seat, unctuous, } \\
\text { strengthening increases Pitha and Rakta, mitigate } \\
\text { Vata (when cooked in ghee it is good for eyes), } \\
\text { cures Rakta and Pitha diseases }\end{array}$ & (Poori) \\
\hline 10 & Ksheerika & $\begin{array}{l}\text { Difficult to digest, stoutening, strengthening, } \\
\text { causes flatulence, mitigate Pitha, bleeding dis- } \\
\text { eases, athyagni and Vata }\end{array}$ & (payasa) \\
\hline
\end{tabular}

There mention almost 64 items of prepared food in bhavapraksha and when coming to brihat triyees there also mention many prepared food items. As nidana as padhya as well as for treatment. but detail preparation method and their therapeutic use is mention in bhavapraksha only. 
When going through all these we can understand each food have some special therapeutic effect and some of food item should not intake in daily basis. but now as day when we look into our diet we can see that intake sweet, bakery items are more as well as intake of continental food and other dishes which not suited for our climatic condition as well as our health are now taken in a daily basis. And they become they are our part of life now.

\section{DISCUSSION}

\section{Olden days food habit and health}

In olden days, people had pazhamkanji, tubers, rice etc for meals and also, they have the habit of taking food in full stomach. Due to their lifestyle together with hard working nature, their body possessed the power to digest heavy meals. But today sedentary life has contributed to less digestive power and so these foods if taken also, they feel heavier to digest. Now due to various conditions like diabetics, cholesterol etc the consumption of rice has decreased.

At present, people mostly consume food preparations like dosa, idili, puttu etc which were commonly using for breakfast and dinner time. Thus, the use of masha or black gram gets increased and that will cause many changes in our body.

In olden days, agriculture being a part of our tradition, people mostly used vegetables that are mere cultivated in own land.

That means at that time food which are accustomed and based on region, season etc were commonly used. But in present era, people use vegetables more from market which are mostly cultivated using pesticides.

Kerala being a coastal area, mostly preferred fish among non-vegetarian items. But the current scenario has changed, and meat has emerged as an important non- vegetarian item for people. The quality of these non-vegetarian items also decreased now a days. The use of dry fish has decreased a lot due to its more smell and increased content of salt.

In early period, in Christian community from particular area used asafoetida in cooking non-vegetarian dishes. But commonly it is used extensively for preparing dishes like sambar, rasam and pickles. In olden time, people prepared paste of spices for various dishes at home itself freshly. Now the convenience of using packed curry powders have lured people to use them. This has in turn affected the health as the curry powders may be made from adulterants and are added with preservatives. In ancient time, rock salt was the only choice of salt available. Powdered salt was introduced to India in the late 1950's as iodized salt i.e. edible salt mixed with a minute amount of various salts of element iodine to prevent iodine deficiency.

Coconut oil, which was plenty available, and homemade was the only choice of oil in olden days. But in later period different other types like sunflower oil, palm oil was used extensively. While analysing the data from survey we can find even though many diseases related to fat intake are more in present scenario but intake of oil decrease when compare to olden days. This may be due to lack of good quality oil now a days and consumption of fat in various other forms. People used jaggery and palm sugar for sweetening the dishes during olden times. But now processed sugar has evolved as the single and hugely available leader among sweetening agents.

Except rice, the prepared food was usually not used for next day in olden days and only fresh vegetables and food articles were used. But now with the introduction of refrigerators to households, people relied as refrigeration method to preserve all types of food. In early days utensils like earthen vessels, Iron vessels, vessels made of steel, brass were common. But in its place, now nonstick vessels were common for preparing food. In present era, the use of pressure cooker also increased which makes the cooking process very fast, which is not good according to dietetics.

The increased number of hotels, changing working hours, frequent travelling needs, and the different types of jobs have clearly augmented the percentage of people dining out. In olden times, joint family system prevailed in Kerala. It was a custom for them to dine together and this has disappeared from the society these days.

In olden days, for drinking most common type of water used was plain water from well and rice water. Now due to different pollution, the only water safe to use is 
boiled water and it is commonly using. Due to lifestyle modifications, the custom of using rice water which is very nutritious become vanished in present scenario. It can be found in Kerala belonging to tropical area expecting hottest month from mid-February to mid may when the use of hot, pungent and bitter foods should be avoided or reduced to minimum so as to preserve the health and strength of the body. The use of locally available fruits in the season help to manage this condition. Similarly, in rainy season water source become so impure that purified water should be used by taking boiled water for drinking and cooking purpose.

Minor changes in one's eating habits can lead to major changes in his health. What is eaten not only affects the day-to-day health but also helps to determine the quality and span of life. Thus, food play a prominent role in providing physical, mental and social well-being of human, which is otherwise known as health

The dietary habit of the people very to great extent depending upon the cultivation of crops in the specific locality, regional availability of various food stuff. There is habitual intake in various communities, economics status etc. Geographical and cultural variation also reflect input pattern the food pattern

Food preparation followed in different part of the same state are different. even the prepared for that mostly curry dishes vary in different regions as clearly evident by the taste and the ingredient's used by the different community's race, etc. As the food style differed from one place to another, house to house and so on, a dietary pattern as such as not obtain as to evaluate it on the basis of preparation. besides this, the choice of food will from individual to individual

\section{CONCLUSION}

Some food preparations and regimen are becoming the part of the life in this modern lifestyle of, so many are unwholesome for the body. The emergency of bakery, preserved, canned and fast food items raise a new culture. Even if it meets the need of four convenience, much is a lot loss in the process of preparation. The life force which cannot be measured in terms of modern parameters as vitamin mineral or calories is destroyed or reduced by the artificial preparation. Devitalized and demineralized foods lower the vitality and sap up the health of the people who fall victims of disease easily. Nothing can be supplemented for the natural abode of the nutrition supply. As raw nuts, fruits and vegetables which are on a decrease in the diet being substituted by the complicated preparations of fat and non-vegetarian items. The more departed from the natural living habits the most suffering will ensue. Foods are altered, treated, processed, coloured, sulphurated, embalmed, adulterated, preserved, pickled, cooked sterilised and pasteurized leading to deprivation of nutritional values, which is the curse of this age. special preparations arrived in the market in the form of tables, tonic capsules and syrup claiming miraculous effect through the commercial advertisement and seems to bind a ready sale to the credulous miss informed public. The modern society was merged into regimens of tea, coffee, colddrinks, instant food, bottled and canned foods, alcohol consumption, smoking drug addiction and so on. The fruits and vegetables suiting for cold climate and region have been imported and is on high demand among the public. It is now very late to identify that as non-congenial to our hot, tropical climates. Thus, a necessity of rethinking the suitability according to seasons, places, climates, temperaments, occupation, way of life etc, is the matter of the hour. So, it is wise to consider and ponder over the problem in a very critical manner and analyse various merits and demerits to rearrange them for the upliftment of good health and living.

\section{REFERENCES}

1. Susruta, Susruta Samhita, Nibandhasangraha Commentary Of Sri Dalhanacharya, Edited By Vaidya Yadavji Trikamji, Chaukhamba Sanskrit Sansthan, Varanasi.2014 Edition. Sutrasthana 46/1

2. Agnivesa, Caraka Samhita, Revised By Caraka And Dridhabala, Ayurveda Dipika Commentary Of Cakrapanidatta, Edited By Vaidya Yadavji Trikamji Acharya, Chaukhambha Publications, New Deihi.2018 Edition; Sutrasthana21/35

3. Agnivesa, Caraka Samhita, Revised By Caraka And Dridhabala, Ayurveda Dipika Commentary Of Cakrapanidatta, Edited By Vaidya Yadavji Trikamji Acharya, Chaukhambha Publications, New Deihi.2018 Edition; Sutrasthana25/30 
4. Https://Www.Firstpost.Com/Brands/Unhealthy-IndiaThe-Rise-Of-Lifestyle-Diseases-In-The-Country4402227

5. Agnivesa, Caraka Samhita, Revised By Caraka And Dridhabala, Ayurveda Dipika Commentary Of Cakrapanidatta, Edited By Vaidya Yadavji Trikamji Acharya, Chaukhambha Publications, New Deihi.2018 Edition; Chikiltsa Stanam

6. Bhavamishra, Bhavaprakasha, Edited By K.R. Srikantha Murthy, Chowkhamba Krishnadas Academy, Varanasi; 2004, Kritha Annavargam.

\section{Source of Support: Nil}

\section{Conflict of Interest: None Declared}

How to cite this URL: Niranjana Gopal K et al: Changing Food Habit - A Re-Evaluation. International Ayurvedic Medical Journal \{online\} 2021 \{cited May, 2021\} Available from: http://www.iamj.in/posts/images/upload/1011_1017.pdf 